\title{
GENESIS OF COALITION POLITICS IN INDIA: A REVIEW OF EARLY TO PRESENT
}

\author{
Rajkumar Singh $^{*}$ \\ Chandra Prakash Singh ${ }^{* *}$
}

\begin{abstract}
In the election of 17th Lok Sabha held in mid-2019, the Indian political parties tried hard to be a tie-up with each other against the present Modi-led NDA dispensation. In independent India, first, such attempt was made early in 1974 and started a new process of consolidation of opposition forces by the merger. In line, the Bharatiya Lok Dal (BLD) was formed by the merger of seven political parties and in this process, the constituent units lost their identity in the BLD. At the time although Congress $(O)$ and the Jana Sangh were ready to cooperate but refused to lose their existence. Their experiences of emergency proved a blessing for them and they came together and formed an alliance called Janata Party, to challenge the Congress leadership of the time. Likewise, as of today in 2018-19 the Bharatiya Janata Party is the country's largest political party in terms of representation in the national parliament and state assemblies and all political parties of present-day India with Indian National Congress as forerunner with the help of regional party try a futile attempt first to challenge and then to defeat the BJP in various elections. Although with a great difference in the situation the motto of opposition parties has been one and only to give weighty protest to turn the events in their favour. This ups and downs of Indian politics may prove a path-breaking for other developing countries where political parties are struggling hard to gain power but did not succeed on account of causes best known to them.
\end{abstract}

Keywords: Political parties, government, opposition, electoral politics and power

\section{Introduction}

The declaration of Parliamentary elections in 1977 followed the release of leaders and workers of different political parties and there emerged a milieu congenial to the flowering of democratic institutions in a healthy atmosphere. Immediately after their release, the opposition leaders of four major non-communist parties - the Congress (O), the Jana Sangh, the Bharatiya Lok Dal, and the Socialist Party announced their merger to form a new party at the instance of Jaya Prakash Narayan for giving a united fight to the Congress. Meanwhile, the Indian National Congress faced a further jerk when a noted scheduled caste leader Jagjivan Ram along with H.N Bahuguna and Nandini Satpathy, left the INC and shook hands with the newly formed Janata Party which also entered into

\footnotetext{
* Rajkumar Singh, Ph.D. Professor \& Head, Post-Graduate Department of Political Science, BNMU, West Campus, Saharsa, Bihar, India

** Chandra Prakash Singh, Ph.D. Professor, Department of History, BNMU, West Campus, Saharsa, Bihar, India
} 
an alliance with some regional parties - the DMK, Akali Dal and CPM. The Congress leaders widely criticised the Janata Party as 'hotchpotch' and its unity a façade. In the circumstances Jaya Prakash Narayan, the chief mentor of the time, explain the whole idea relating to socialism under which the party was formed. 'It is not born out of expediency but out of the realisation of political necessity. The opposition parties have realised that if the country has to be saved for democracy they must come together not merely as an alliance but as one single party ${ }^{1}$. He also said on the occasion that the party was committed to Gandhian principles in evolving its socio-economic programme. After the merger of constituent units and formation of a front, the Janata Party decided to contest elections on a common programme and a common symbol. The opposition front made the Emergency and its excesses, especially forced sterlizations and the restrictions of civil liberties, the major issues of its election campaign.

\section{Objectives}

The objective of the study relates to the historical and modern development of political parties in India and also narrates its several ups and downs in the political life of Indian nation. As it is clear from its historical graph that the country had started its political journey with the dominance of a single party called Indian National Congress, but latter political developments marred the prospect of Congress party and it's decline started in mid-sixties in provinces and in afterwards in 1977at the Centre. It was also a lively beginning of vote bank politics in India as it divided the society as a whole in different segments and at the same time invited polarisation of votes on caste and communal basis. In the light of several developments happened so far in Indian politics the paper aims to identify the following facts ;

1. Basics of India's political party system,

2. Beginning of political consciousness in India,

3. Major political developments in sixties and seventies,

4. Nature and features of coalition politics in India, and

5. Dominance of religion-based politics in the country.

\section{Debacle of Janata Party}

The Janata experiment failed on two counts: Firstly, it adopted the manipulative politics of Congress Party by dismissing its governments in states, although it had declared in its manifesto that since there had been a high degree of centralisation, it would pursue the decentralisation of economic and political powers ${ }^{2}$. The second cause of its decline was intraparty rivalry which started by the end of 1977 and climaxed in 1978-79. By mid1979 - the squabbling and bickering in the party came to the fore and each group wanted for themselves as much space as possible. As a result, the alliance became a symbol of factionalism, manipulation and personal ambitions of its leaders. Basically, it was a coalition of parties having traditionally, ideologically and programmatically an unequal

\footnotetext{
${ }^{1}$ Hasting, James. Encyclopaedia of Religion and Ethics (USA: Charles Scribner's Sons, 1959), p. 192.

${ }^{2}$ Munshi, K.M., Pilgrimage to Freedom (Mumbai: Bharatiya Vidya Bhavan, 1967), p. 66.
} 
base but united only to attain political power ${ }^{3}$. Janata Party's character as a ruling party was quite different and it was more a contingent formation than the result of a genuine political realignment representing a coalition of social interests ${ }^{4}$. Its awfully conglomerate character deprived it of a reasonably unified leadership and outlook. Infighting in the party at the state level had an adverse effect on its national leadership. Though the Party emerged as a result of a broad consensus among many parties and leaders, it failed to contain the conflicts, which jeopardised the moving and delicate equilibrium of consensus.

In fact, the Janata Party was not a party in the true sense of the word but a hurriedly formed coalition of political parties having conflicting ideologies and clashing constituencies $^{5}$. The political ambitions of all the leaders of various fractions - Morarji Desai of Congress - O, Charan Singh of BLD, Jagjivan Ram of CFD and Chandra Shekhar of the Socialist faction had resulted in a consistent and brazen struggle for office. In addition, the party's task was greatly complicated by the personality factor. The Party had Morarji Desai as its Prime Minister who was temperamentally incapable of presiding over what was essentially an alliance. Not that he was intellectually and morally inferior to the front-rank politicians in the Congress or in terms of political experience and administrative ability he was second to anyone. His obstinacy, his one-track mind, and his well-known fads singled him out as man and a colleague difficult to get along with. He had cultivated a doubtful virtue of never bending even when the alternative was breaking. This may be the most precious, most sterling quality of a saint or a moral preceptor, but in a politician, it was the deadliest trait. Whatever be the political, administrative system, compromises are the staple of politics ${ }^{6}$. The formation of the Janata Party could have been a net gain for the nation if the leadership, in fact, had the courage to take the merger decision of its constituents to its logical conclusion. It's two other most important figures - Charan Singh and Jagjivan Ram were hardly on speaking terms. They perhaps believed that the clash between them was an expression of the most fundamental conflict in the countryside, the conflict between the landed intermediate caste and the landless labour.

The sectarian tussle in the Janata government and the Party took a critical form in the middle of 1979. Earlier Charan Singh, the Home Minister, had been forced to leave from the cabinet on 30 June 1978, and was then, brought back as Finance Minister in January 1979. This ultimately led to a split in the party and the formation of Janata Party (Secular) by BLD leader Charan Singh and the fall of Morarji Desai - led Janata Party government. In July 1979, the Janata Party had to leave the Government at the Centre. The Desai's government came to an end in mid- July 1979 and after a brief interval of one week Charan Singh formed the government but unfortunately, he never got to face the parliament as, on 20 August, a day before the confidence vote, Indira Gandhi

\footnotetext{
${ }^{3}$ Gwyer, Maurice and Appadorai A., Speeches and Documents on Indian Constitution (Bombay: Oxford University Press, 1967), p. 548.

${ }^{4}$ Rao, Shiva B., The Framing of India 's Constitution - A Study (New Delhi: The Institute of Public Administration, 1968), p. 745.

${ }^{5}$ Subhash, Manju. Rights of Religious Minorities in India (New Delhi: National Book Organization, 1988), p. 141

${ }^{6}$ Gupta, Das S., "Regaining the Faith”, India Today, April 8, 2002 (New Delhi, 2002), p. 32.
} 
withdrew her support. In line, Charan Singh advised the president to dissolve the Lok Sabha and a mid-term election was announced to be held in January 1980. For the first time in India, a two party-system seemed to gain salience and it was in existence from 1977 to 1979 when only two parties-the Janata and the Congress accounted for over 80 percent of votes and seats ${ }^{7}$. Had this trend continued, the two-party system would have prevailed in India. But the developments of 1979 put a curb on it. The emergence of the two-party system was merely an outcome of specific circumstances and a matter of mutual convenience ${ }^{8}$. The first coalition government at the Centre could not continue more than 28 months due to a tug-of-war among the different leaders of the Janata Party and the country was left to have a fresh mandate. Clearly, the formation of coalition government became a game of selfish, opportunist power hungry and unscrupulous politicians who had to look after nothing but their personal interests. This scenario gave rise to the notion that Parliamentary government and coalition arrangement could not go hand in hand ${ }^{9}$. Especially when Mrs. Gandhi staged a come-back the widely created impression was that coalition government cannot work at the apex of the political and administrative arrangements. It can work only in the States under the aegis of the Union Government constituted by a single party and led by a powerful and charismatic leader.

\section{Literature Review}

\section{Seventh Lok Sabha Election}

The election results of the seventh Lok Sabha held in January 1980 showed that the people of India had repudiated the charges of authoritarianism, arbitrariness, abuse of power and personal corruption against Mrs. Indira Gandhi. Clearly, the results of 7th Lok Sabha, held in January 1980 went in favour of Indira Gandhi and she came back once again with a thumping majority of 353 in the House of 529 seats. While in the election campaign the opposition parties blamed Indira Gandhi for excesses of emergency, the latter was successful in convincing the public about Janata government's nonperformance and appealed the masses to choose a 'government that works ${ }^{10}$. By electing Mrs. Gandhi and her nominees in an overwhelming majority the people of India had given themselves another chance to continue the task of building a viable nation-state. Once again the country gave the office to a leader who was firmly in command of her party and whose appeal cut across all the great divides in the Indian community-religious, social, linguistic and regional. On the other hand, the Janata Party had betrayed the trust of the people by its failure to hold together and to address itself to the urgent problems of the country. In the absence of a strong leader and a well-defined ideology the desire to keep Mrs. Gandhi out of office was not strong enough to keep them united. In voting Mrs. Gandhi to power the electorate had responded to her promise of stability, security and efficient administration. At the same time, it had also punished Janata Party for its failure on a number of fronts including the economy and law and order.

\footnotetext{
${ }^{7}$ Ibid.

${ }^{8}$ Ali, Dr. Asghar Engineer, "Who is for a Common Civil Code?” The Hindustan Times, August 3, 2003 (New Delhi: 2003)

${ }^{9}$ Singh, Rajkumar. Past, Present and Future of Kashmir (New Delhi: Gyan Publishing House, 2008), p. 65.

${ }^{10}$ Ali, Dr. Asghar Engineer, Op.Cit.
} 
The 1980 Parliamentary elections helped the Congress (I) led by Indira Gandhi in restoring one-party dominance on account of her promise to give a government that works and due to the disenchantment of the voters with the political instability created by the leaders of the Janata Party. Moreover, the projection of Mrs. Gandhi as being a champion of the minorities and the weaker sections also enabled her party to regain its lost support base ${ }^{11}$. However, on having assumed office she adopted the same old styleplacing total reliance on small coterie, extensive use of media for personality projection and deferring of organisational elections in the party. After her coming, she got the Janata governments in nine states and dismissed them through Article 356. Though Congress came to power in some of the states yet in Andhra Pradesh, Tamil Nadu, Jammu and Kashmir, Karnataka and West Bengal non-Congress governments were formed. The governments in these states were basically regional party governments. They started clamoring for less intervention by the Centre and more participation by the states in the policy formation of the country. In this context, Indira Gandhi appointed the first ever constitutional review commission on Centre-State relations in 1983 headed by Justice R.S Sarkaria of Supreme Court of India. At the organisational level, like earlier, her major weakness was the continuing organisational weakness of Congress and her failure to rebuild it and strengthen its structure. This inevitability affected the performance of the government and its popularity, for a weak party structure meant the choking of channels through which popular feelings could be conveyed to the leadership and the nature and rationale of government policies explained to the people. Apart from this the second inning of Indira Gandhi also confronted certain inflexible problems relating to communal, language and caste struggles which continued in her regime.

In the circumstances, the most unfortunate for Indian polity was the continuing split and extreme differences among political parties at the national and state level. Earlier after the Lok Sabha elections of 1980, the Janata Party witnessed further division. This breakup was not on the basis of programme, principles or ideology but on account of personal conflicts. Charan Singh and Rajnarain broke up into Janata Party (Secular-Charan) and Janata Party (Secular-Rajnarain). The original Janata Party under the Presidentship of Chandrashekhar had to rely on the name of the founder Jayaprakash Narayan, to keep itself going and became Janata Party (J.P). In a further development, another ally, the old Jana Sangh left Janata Party and formed Bharatiya Janata Party at the close of 1980 under the chairmanship of Atal Bihari Vajpayee. Jagjivan Ram also joined Congress(U) and thus, kingpins of India's democratic political structure, gradually became the feeblest bond in the country's political system. Explicitly, the political parties of India were on a decline due to inter and intra-party uncertainty, extreme fighting, factionalism within parties, weak and inept organizational structure, which ultimately led them to disintegrate. As a result, there were large changes at the middle and lower levels of the party and shift of loyalties from one party to another. This development adversely affected democracy and support to developmental programmes, welfare, and social justice policies at large. Consequently, in India, political parties cannot easily build a strong and viable opposition, however, skillful, principled and determined they may be. Indian society is inherently incapable of sustaining the Westminster model of Parliamentary democracy if this implies the existence of two parties of nearly equal

\footnotetext{
${ }^{11}$ Singh, Natwar K., “Truth’s Messenger”. The Hindustan Times, January 30, 2003 (New Delhi: 2003).
} 
strength so that the one in opposition can easily take over the task of running the government if the ruling party fails to deliver the goods and forfeits popular support. It is a highly disturbing conclusion for all those who believe that Parliamentary democracy is best suited to meet India's needs.

\section{Post-Indira Phase}

After the assassination of Mrs. Indira Gandhi on 31 October 1984 her eldest son Rajiv Gandhi became the new Prime Minister of India the same day. Even during her tenure from 1980-84, she pursued the politics of confrontation instead of consensus that aggravated the crisis in Punjab and Assam. Besides, deviation from the path of socialism led to the alienation of weaker sections and non-adherence to secularism began to alienate the minorities. Her mishandling of the demand of a separate Sikh State was accompanied by her refusal to understand the socio-political changes occurring across the country and manifesting themselves mainly in the form of regional assertion. The brutal death of Mrs. Gandhi followed the Eighth General Election held from 24-27 December 1984 in which the Congress won a historic majority of 415 out of 543 Lok Sabha seats. The projection of the clean image of her successor, Rajiv Gandhi, by the media on the one hand, and the subtle use of Hindu card ${ }^{12}$ by the Congress (I), on the other, enabled this party to receive a massive mandate in the 1984 Parliamentary elections. The sympathy wave caused by the assassination of Indira Gandhi was also a vital factor in his victory. It gave the Congress a three-fourth majority in the Lok Sabha and an assurance to millions of people that a stable government ensuring peace and effective governance elusive for a period of time, had returned. On the other, the election held in the aftermath of Mrs. Gandhi's assassination reinforced the one-party dominance of Congress (I) under Rajiv Gandhi's leadership and virtually put the national opposition to political disarray and wilderness. There was only one important issue in the elections, namely, the unity and integrity of India. The euphoria generated by Rajiv's massive mandate subsided a number of scandals against the central government, the failure to solve the Punjab problem and the government's nonperformance on the socio-economic fronts.

The political process in the period of Rajiv Gandhi was marked by a "crude combination of technologies for the elite and communalism for the masses. He set up 'technology missions' to apply science and technology in six areas of underdevelopment in order to solve pressing problems. But some parties like the BJP found in communal politics a new lease of life for themselves. Increasingly, Mullas, Sadhus, and Jathedars assumed political roles that ought to have been played by the Party leaders. Rajiv Gandhi had earned considerable goodwill by initiating peace processes of political disputes through negotiations. He adopted the style of consensus and signed accords for ending militancy in Punjab and Assam. Although he was successful in Assam, he failed in Punjab owing to several reasons. In a landmark decision, Rajiv Gandhi and his government decided to take initiative to deepen and strengthen Panchayatiraj institutions and brought forward legislation to make its timely elections mandatory by providing them a constitutional sanction. He made his intentions public at the centenary celebrations of the party in

\footnotetext{
${ }^{12}$ Kapoor, Suneera and Shrawan Singh, "Gandhi and Nehru on Religion". Indian Journal of Political Science,
} vol. 66, no. 3, July-September 2005 (Meerut: 2005), p. 503 
December-1985 to restore inner-party democracy and to free it from the power brokers ${ }^{13}$. In his speech, he promised to revive the party by eliminating their stronghold. It was read as an indication for the old leaders to get their acts altogether, but many party-men with not so good record refused to appreciate this disrespectful style of functioning. The elections of 1989 were held in an environment charged with emotion variously by the anti-corruption campaign in which Rajiv Gandhi was the main target. He had not only to face the charges of corruption in the purchase of Bofors Gun but the vocal opposition of V.P. Singh-led faction that contributed significantly to the end of the dominance of the Congress (I) in 1989 Parliamentary elections.

\section{Methodology}

The research methodology in this study aims to unfold and analyse the complexities of Indian political system of last seven decades which has given the party system a new shape in current day politics. Decades of coalition experience in India have varied dimensions which have fastened the colourful scenes in Indian politics and society as well. As the available materials on aspects of Indian political life are mostly descriptive, analytical and theoretically ambiguous, the research used secondary sources-books, journals, and newspapers, internet at times quantitatively to explain and analyse events leading to the present state of affairs. At large the study relies on collected facts/materials because it would help to test the hypothesis.

In course of the study, main focus remained on different dimensions of related aspects and therefore, the work has excluded otherwise very useful narrations of other contexts to concentrate solely on study focus.

\section{Discussion and Results}

The 1977 Parliamentary election resulted in the victory of the Janata Party and the defeat of the Congress due to a strong anti-Congress wave. The people treated the elections as a plebiscite on the Emergency. With the widespread rise in favour of them, the Janata Party and its allies became victorious with 330 out of 542 seats. The Congress had to be contended with 154 seats only, while its ally CPI was fixed on 7 and AIADMK on 21 seats. The election results were described -" second liberation", "ballot revolution", "popular upsurge", "elections without parallel". For most observers, it was the commencement of a new process of political consolidation. In fact, it was that extremes during the family planning drive and stories of irritation and coercion, particularly affecting the Muslims, the Harijans and the backward classes, and exaggerated figures of casualties in police firings. All alienated a large section of the Muslims and the Harijans from the Congress Party and that this was a decisive factor in its defeat ${ }^{14}$. In the elections, the Congress Party had secured 34.54 percent of the votes against 43.17 percent of the Janata Party. A drop of 8.52 percent from the 1971 poll had cost the Congress party as

\footnotetext{
${ }^{13}$ Sharma, Urmila and Sharma, S.K., Indian Political Thought (New Delhi: Atlantic Publication and Distributor, 1966), p.305.

${ }^{14}$ Gokhale, B.G. Indian Thought Through the Ages (New Delhi: Asia, 1961), p. 103.
} 
many as 197 seats $^{15}$. In nutshell, the Congress defeat can be accounted to the 18 -months of authoritarian rule, forced sterilization, resettlement, beautification of cities and the bulldozing programmes. These were in addition to the rampant corruption in the administration, nepotism, and operation fund collection by the party workers. Consequently, the Janata Party had not got positive support for its programmes; but it had got only negative support as an alternative to the Congress. In it, the people had shown their capacity to discipline an arrogant government; however, it turned out to be a referendum on certain aspects of the emergency and not an election on clear-cut socioeconomic programmes. It was a case of personalised politics in which there is a strange relationship between an individual and an organisation. Firstly, it is the party organisation which imposes a leader from above; he does not emerge from the grassroots. This leader later receives a hero's treatment and develops arrogance. He creates a halo of sycophants and also a clique. Then after, he is not guided by the organisation but controls $\mathrm{it}^{16}$. In such a system an individual has the capacity to do immense harm to the party.

The post-emergency phase of Indian politics was marked by the assumption of power by the Janata Party by dislodging the Congress from the Centre consequent upon the sixth general election of 1977. The national politics underwent a fundamental change when a coalition government headed by Morarji Desai was formed on 24 March 1977. The Janata Party emerged as an alternative to the Congress and led to speculations about the prospect of political polarisation in the country. It appeared that a two-party system had ultimately emerged in India because the Janata Party asserted as the ruling party and the Congress was the major opposition party. Since Independence, it was the first trial of coalition politics at the centre in which allies failed to garner mass support and disappointed the masses on several counts. It's an unsatisfactory role in an administration and development policies proved a hurdle in realizing social justice. It also failed in handling growing social tension which paved the way for dividing the society into rich and poor. Increasing brutalities on rural scheduled caste poor were also on the rise, especially in North India. At that point, the earlier social division of caste and creed was sharpened and even the rural landowners became a critic of the Janata government. Clearly, they were opposing the empowerment of rural poor which was the root cause of social tension in rural India. On the other hand, rural poor and lower castes of society became more conscious about their rights and were afraid of the functioning of democracy and adult franchise ${ }^{17}$. On economic front the Janata government denied Nehruvian model but failed to provide any alternative to the economic problem of distressed people at large.

In economic terms, the rule of Janata Party which took over the reign in March 1977 hardly made any visible impact except on some multinational companies like IBM, Coca Cola and others operating in India since long. It was due to the passing of Foreign Exchange Regulation Act (FERA) which came into being in 1974 and the new law placed a cap on foreign equity participation at $40 \%$. In the context the new government's

${ }^{15}$ Bharatiya, B.P. Religion - State Relationship and Constitutional Rights in India (New Delhi: Deep and Deep Publications, 1987), p. 16.

${ }^{16}$ Rizvi, Md. Mahtab Alam, "Secularism in India: Retrospect and Prospect", Indian Journal of Political

Science, vol, 66, no. 4, October - December 2005 (Meerut: 2005), p. 903.

${ }_{17}^{17}$ Derrettee, J. Duncan M., Religion Law and the State in India (New York: Free Press, 1968). 
decision to become more insular and focus on promoting agriculture, rural and indigenous industries had made the economy unsuitable for the multinational companies. Basically, in this period there was no real attempt at operating a new policy despite the claim by the party that it had given a Janata economic blueprint. In fact, the party was dominated by socialists who swear by nationalisation and pro-poor schemes and as a result, the Janata government tried to strengthen the role of the public sector and made more difficult for multi- nationals and foreign capitals to come in with new technology. It believed in state control of all productive resources including capital, but there was no real departure and the Janata government failed to provide any suitable alternative economic policies for the country.

\section{Conclusions and Pathways}

The period also witnessed in Indian politics the rapid popular reversal of moods. The electoral process and the outcomes of elections, as well as the structuring of political responses between them, were breached. The same people who voted the governments in with huge mandates soon turned against their own government, and the Indian state was under constant popular assaults. The Janata government which followed the defeat of the Emergency regime and which restored democracy faced the same situation of popular agitation. Once in power, the Janata with its regional base confined to the north Indian Hindi heartland fell prey to its own internal contradictions. The same was the case in 1980 and 1984. This is an important indicator of the unresponsive nature of the ruling class vis-a-vis the problems of the people, and the lack of adequate accountability of the government of the day. This phase of politics devalued the leaders, political parties and certain institutions which lost their autonomy and were converted into mere instruments of powers.

The decade 1980s exhibited the declining strength of Congress's claim to power at an effectively unitary all-India centre and therefore, the Party substituted its populism with implicit, if not explicit, to religious majoritarianism. Communalism against regionalism was a well-tried formula of the colonial state. Its implementation in this period must be placed squarely in the context of the many powerful regional challenges to central authority. As ideologies of secularism and socialism lost credibility the Congress regime turned implicitly to region-based majoritarianism to meet regional threats. Earlier in 1970s and 1980s several regional political parties, such as TDP, in Andhra Pradesh, Akali Dal in Punjab and others in different parts of the country claimed to have achieved national status and some of them, especially more extreme elements of the Sikh religious community launched a violent campaign for the attainment of a separate Sikh homeland called Khalistan. It culminated in the brutal assassination of Indira Gandhi in October 1984 by her Sikh bodyguards and her son Rajiv Gandhi registered a record-breaking victory in the 1984 elections with the help of sympathy wave and Hindu card. Viewing Indian society through the colonial lens that revealed a majority and a minority community based on the religious distinction, the new regime took a couple of decisions. On the one hand, Rajiv Gandhi's government opened the doors of the Ayodhya mosque to Hindu worshipers. On the other, in a curious and ill-advised attempt to placate Muslim opinion after India's judicial system had awarded alimony to Shah Bano, he railroaded 
through Parliament a deeply conservative Muslim women's bill. The new steps appeared to give a new lease to the continued exercise of central authority by Congress.

\section{Future Works}

In India the coalition system of government is the outcome of the failure of the Parliamentary system to satisfy the norms of getting absolute majority of seats in the Lower House to form the government. It is an alliance between two or more hitherto separate or even hostile groups or parties formed in order to carry on the government and share the principal affairs of the state. A coalition government is formed when more than one political party or group comes together on the basis of common understanding or agenda. The immense social plurality in India will, obviously reflect itself in its polity. It is only natural that under these conditions various parties may garner the confidence of sections of this vast social diversity and thus no single party may acquire the requisite majority to form its own government. But such fractured mandates carry with them an important element of 'checks and balances' required for the sound functioning of any democracy. For this reason, coalition governments of today should have a common minimum programme of policies to be implemented while in office.

Coalition governments all over Western Europe have worked very successfully because of broad-based consensus and the underlying willingness to function together for good governance. But in India's case the scenario is drastically different and there is no early prospect of durable and effective unity at the national level. The BJP has little or nothing in common with the other political parties-Right, Left or Centre. For good or ill the party is looked upon a fundamentalist organisation wedded to Hindu revivalist policy or Hindutva. In it the question of who is an Indian is determined by the person's religious denomination. The worth of human beings should be defined in terms of features, abstract and general, such as dignity, respect and concern. The use of specific criteria like religion, culture or prefixed history can result in inequality and cause serious trouble. For the BJP being a Hindu makes a person more of a human being. Humanness is determined by religious denomination. Even the socio-economic programmes of the BJP are quite different from the programmes of other parties. The communists have been following improvised socio-economic programme designed to suit the circumstances more than to conform to Marxism. Other political parties including the Congress, have no distinct socio-economic programme. As a result 'the process of bipolarisation will remain a far off thing so long as factionalism, rivalry are chronic in the major political parties; bases of political action lie in such irrational factors like caste, community, region, language, creed, personality and charisma; the fight for power is not imbued with some altruistic motive and does not reflect the social and economic urges of the masses. The realignment of political parties remains an uncertain factor in Indian politics.

At present the sole objective of political parties is to stay afloat and capture or share power with other political parties wherever and whenever possible. They are not averse to entering into alliance or electoral understanding, or even shake hands with the devil himself if that gesture can help them capture power. There are casteist outfits, ethnic organisations, regional parties, each operating within the given parameters and without any qualms of conscience ready to hitch their wagon to the rising star. The Congress, the 
Communists and Socialists have nothing to do for the time being, with the BJP. Others being not so obstinately opposed to the BJP, would get along with it merrily. In the situation horse trading has become the part of political system. A Prime Minister or Chief Minister heading a coalition government dare not drop a corrupt minister so long as he commands the support of a coalition partner, unless he is prepared to risk the fall of his government. Integrity and ability are no longer the main criteria for appointment of minister. But on the other the contemporary scenario of politics has also contributed to a definite change in the level of political socialisation, interest articulation, interest aggregation and political communication. In every polity there is a period of political stagnation, uncertainty and instability. India is a developing democracy where democratic traditions are evolving with the passage of time. Likewise it will take time for the political parties to mature and come to the level of general expectations.

\section{Bibliography}

Ali, Dr. Asghar Engineer, "Who is for a Common Civil Code?" The Hindustan Times, August 3, 2003 (New Delhi: 2003).

Bharatiya, B.P. Religion - State Relationship and Constitutional Rights in India (New Delhi: Deep and Deep Publications, 1987).

Derrettee, J. Duncan M., Religion Law and the State in India (New York: Free Press, 1968).

Gokhale, B.G. Indian Thought Through the Ages (New Delhi: Asia, 1961).

Gupta, Das S., "Regaining the Faith”, India Today, April 8, 2002 (New Delhi, 2002).

Gwyer, Maurice and Appadorai A., Speeches and Documents on Indian Constitution (Bombay: Oxford University Press, 1967).

Hasting, James. Encyclopaedia of Religion and Ethics (USA: Charles Scribner's Sons, 1959).

Kapoor, Suneera and Shrawan Singh, "Gandhi and Nehru on Religion". Indian Journal of Political Science, vol. 66, no. 3, July-September 2005 (Meerut: 2005).

Munshi, K.M., Pilgrimage to Freedom (Mumbai: Bharatiya Vidya Bhavan, 1967).

Rao, Shiva B., The Framing of India's Constitution - A Study (New Delhi: The Institute of Public Administration, 1968).

Rizvi, Md. Mahtab Alam, "Secularism in India: Retrospect and Prospect", Indian Journal of Political Science, vol, 66, no. 4, October - December 2005 (Meerut: 2005).

Sharma, Urmila and Sharma, S.K., Indian Political Thought (New Delhi: Atlantic Publication and Distributor, 1966).

Singh, Natwar K., “Truth’s Messenger”. The Hindustan Times, January 30, 2003 (New Delhi: 2003).

Singh, Rajkumar. Past, Present and Future of Kashmir (New Delhi: Gyan Publishing House, 2008).

Subhash, Manju. Rights of Religious Minorities in India (New Delhi: National Book Organization, 1988) 